\title{
Impact of Invasive Alien Species- Acacia nilotica on the Remnant Dry Deciduous Forest of Palu Valley, Central Sulawesi, Indonesia
}

\author{
Mustaid Siregar $^{1^{*}}$, Sutomo $^{1}$, Danang Wahyu Purnomo ${ }^{1}$ and Rajif Iryadi ${ }^{1}$ \\ ${ }^{1}$ Research Center for Plant Conservation and Botanic Gardens, Indonesian Institute of Sciences \\ (LIPI). JI. Ir. H. Djuanda No.13, Bogor 16211, West Java, Indonesia.
}

\begin{abstract}
Authors' contributions
This work was carried out in collaboration among all authors. Authors MS designed the study, collecting data, performed the statistical analysis and wrote the first draft. Authors $S$ conducted additional statistical analyses enhance the discussion and checking the English version of the manuscript. Author DWP, collecting data, enhance the discussion, Author RI, added image analysis of Acacia nilotica and add materials in the discussion. All authors read and approved the final manuscript.

Article Information

DOI: $10.9734 / A R R B / 2021 / v 36 i 730403$ Editor(s):

(1) Dr Paola Angelini, University of Perugia, Italy. Reviewers:

(1) S. S. Meenambiga, Vels Institute of Science Technology and Advanced Studies, India. (2) Shourav Dutta, Rangamati Science and Technology University (RMSTU), Bangladesh. Complete Peer review History: https://www.sdiarticle4.com/review-history/71424
\end{abstract}

Original Research Article

Received 20 May 2021

Accepted 27 July 2021

Published 29 July 2021

ABSTRACT

Aims: The study was carried out to assess the species composition, vegetation structure, regeneration and possible direction of vegetation development due to Acacia nilotica invasion.

Study Design: The study applied the vegetation analysis and remote sensing technique in the deciduous forest of the Palu Valley in Central Sulawesi.

Place and Duration of Study: The study was conducted in Biromuli District, Sigi Regency, Central Sulawesi Province of Indonesia in February 2019.

Methodology: Species composition, vegetation structure and regeneration were studied using the split plot method, while the specific population and distribution of $A$. nilotica were studied using drone photos in an area of 10.24 ha.

Results: Individuals $\geq 2 \mathrm{~cm}$ in diameter are 24 species, 22 genera and 14 families. The main species are Tabernaemontana pandacaqui, A. nilotica and Jatropha gossypiifolia. The ground vegetation 
(diameter $<2 \mathrm{~cm}$ ) contained 21 species, 21 genera and 17 families, dominated by Digitaria ciliaris and A. nilotica. The species diversity index is 2.3880 (moderate), while the species evenness index is 0.75 (unstable). Density of 1.069 individual's per ha and total basal area $2.48 \mathrm{~m}^{2}$ per ha. The dominance of individuals with a diameter of $2.0-4.9 \mathrm{~cm}(62.9 \%)$, followed by diameter of $5.0-9.9 \mathrm{~cm}$ $(32.4 \%)$, and diameter of $10 \mathrm{~cm}$ up $(4.67 \%)$. The canopy layer consists of only one main layer at a height of $4-7 \mathrm{~m}$. Canopy analysis using drone photos showed that $27 \%$ of the total forest canopy area and $32.9 \%$ of the total individuals were controlled by $A$. nilotica.

Conclusion: The dry forest in Sigi is the remnant deciduous forest located specifically in the Palu Valley which is still in the process of development. The invasion of $A$. nilotica needs to be controlled in a sustainable way so that the rest of the forest does not turn into a stretch of $A$. nilotica.

Keywords: Acacia nilotica; Central Sulawesi; Dry deciduous forest; Invasive Alien Species; Sigi.

\section{INTRODUCTION}

Dry deciduous forest or monsoon deciduous forest is a biome dominated by trees that shed their leaves during the dry season and re-grow them in the rainy season [1]. Generally, it is called dry deciduous forest if more than $50 \%$ of the plant species experience leaf fall in the dry season [2]. This forest grows in areas that have a seasonal climate pattern with prominent dry and wet periods, at least 4 consecutive dry months with relatively low rainfall [3-5]. It has a D-H climate type with $Q$ index $>60 \%$, rainfall is less than $1500 \mathrm{~mm}$ per year [2].

In Indonesia, dry deciduous forests spread across Baluran National Park - East Java, West Nusa Tenggara, East Nusa Tenggara, Maluku and southeastern Papua at elevations less than $800 \mathrm{~m}$ above sea level [2-8]. The dryness of these areas is mainly due to monsoon winds which bring about clear seasonal differences in the amount of monthly rainfall [5]. Several tree species are commonly growing in dry deciduous forests of Indonesia include Aleurites moluccana, Acacia leucophloea, Acacia tomentosa, Albizia chinensis, A. lebbekoides, Borassus flabellifer, Dalbergia latifolia, Schleichera oleosa, Schoutenia ovata, Tamarindus indica [2,5].

Dry deciduous forest is a type of forest that is classified as highly threatened; especially by agriculture and burning to obtain grass as animal feed [9]. Similar phenomenon has happened in the Palu Valley for a long time, so there are not many new records about the native vegetation of the Palu Valley on the island of Sulawesi. Sulawesi Island or Celebes is one of the 5 major islands in Indonesia (Kalimantan, Papua, Sumatra, Sulawesi and Java) [10]. Forests in Sulawesi are dominated by lowland tropical rain forest and montane tropical rain forest [11-12]. There is little literature that reports that Sulawesi has dry, deciduous forests. - Whitten and coresearchers [11] - reported that the Palu Valley in Central Sulawesi Province was previously covered with dry - forest, but it is rarely found due to repeated fires. One area that is thought to be the remnant of dry forest in the Palu Valley was found in Biromuli, Sigi Regency, Central Sulawesi. This forest area has an area of not more than 100 ha and is surrounded by agricultural lands in the north, west and south and hills of wet tropical rain forest in the east.

One of the major threats to tropical forests including dry deciduous forests in Indonesia is the presence of invasive alien plant species, such as the Acacia nilotica species originating from Africa, and Sigi Forest is one of those species that has been invaded. This study was aimed to find out more information about species composition, vegetation structure and future regeneration tendencies as well as problems with the invasive alien species (IAS), namely $A$. nilotica. -The results obtained from this study can also be useful - to - manage this area in the future properly.

\section{MATERIALS AND METHODS}

\subsection{About Study Area}

The Palu Valley, is surrounded by hills in the west, east and south and facing the Sulawesi strait in the north.It has a mostly flat and sloping topography with sandy soil. The Palu Valley grew into a residential area, urban area and agricultural land. The earthquake and tsunami that hit Central Sulawesi on September 28, 2018 occurred in the Palu Valley which caused several areas to experience soil liquefaction. The Palu Valley has a climate type $E$ based on the classification of Schmidt \& Ferguson which is characterized by long dry months (> 6 months) and wet months of less than 2 months each year. 
This dry climatic condition forms a dry forest type [11]. The study was conducted in Biromuli District, Sigi Regency, Central Sulawesi Province of Indonesia (Fig. 1). The topography is generally flat to sloping with a slope of $0-8 \%$, consisting of a very thick layer of sand with a depth of up to $200 \mathrm{~m}$. The groundwater depth is more than $60 \mathrm{~m}$. The content of organic matter (C-organic) is generally very low to less than $1 \%$ and increases towards the east where there are hilly areas [13]. Geology consists of rock formations Molasa Celebes Sarasin and Sarasin which consist of conglomerate, sandstone, mudstone, marl and coral limestone, loose and some are somewhat compact [14].

\subsection{Vegetation Sampling and Mapping}

Vegetation analysis was carried out -applying the split plot method. A total of 30 plots $(10 \mathrm{~m} \times 10 \mathrm{~m}$ in size) were placed along a transect that extends from the outer forest edge to the inner forest edge bordering the evergreen rainforest. The distance between -two plots is $50 \mathrm{~m}$. All species $\geq 2 \mathrm{~cm}$ in diameter contained in each plot were recorded with the species name, number of individuals of each species, trunk diameter and tree height. In each plot, plots measuring $2 \mathrm{~m} \times 2$ $\mathrm{m}$ were also made for regeneration sampling (seedlings with diameter $<2 \mathrm{~cm}$ ) and understorey including data on species and percentage of canopy cover for each species. A transect $(7 \mathrm{~m} \times 100 \mathrm{~m})$ was also made to draw the forest profile from the side. Samples of each type were collected for identification purposes. To see in more detail the population of Acacia nilotica, drone images were used in an area of $320 \mathrm{~m} \times 320 \mathrm{~m}$ (10.24 ha).

Mapping image analysis was conducted using digital data image having 8 bit on RGB system. The $A$. nilotica training area was taken for each canopy plot to analyze the class value approach based on the mean and standard deviation (Eq. 1). The standard deviation approach is generally influenced by the distribution of data values for each character of the R (red), G (Green), and (Blue) bands [15-17]. This approach was carried out by taking a logical approach to the calculation results of the statistical values and then grouping the selected vegetation type [17]. This approach was applied because it is easier to classify certain types of classes based on the value of each statistic resulting from the training area.

$\mathrm{CRx}=$ EITHER $1 \mathrm{IF}\left(\mathrm{I}_{R}>S d_{\operatorname{minR}}\right.$ and $\mathrm{I}_{R} \leq S d_{\max R}$ and $\mathrm{I}_{\mathrm{G}}>S d_{\min }$ and $\mathrm{I}_{\mathrm{G}} \leq S d_{\operatorname{maxG}}$ and $\mathrm{I}_{\mathrm{B}}>\mathrm{Sd}_{\min }$ and $\mathrm{I}_{\mathrm{B}}$ $\left.\leq S d_{\max }\right) \quad$ OR $\quad 0 \quad$ OTHERWISE ....................... (Eq. 1)

Where,

$\mathrm{CRx}=$ Class range object $\mathrm{x}$

$I_{R}$ : Value layer Red

$I_{G}$ : Value image Green

$I_{B}$ : Value image Blue

$\mathrm{Sd}_{\text {minR }}$ : Median value Red - Standard deviationi Red

$\mathrm{Sd}_{\operatorname{maxR}}$ : Median value Red + Standard deviaton Red

Note: $\mathrm{Sd}_{\min G}$ and $\mathrm{Sd}_{\max G}$ to $\mathrm{Green}$; $\mathrm{Sd}_{\min B}$ and $\mathrm{Sd}_{\operatorname{maxB}}$ to Blue.

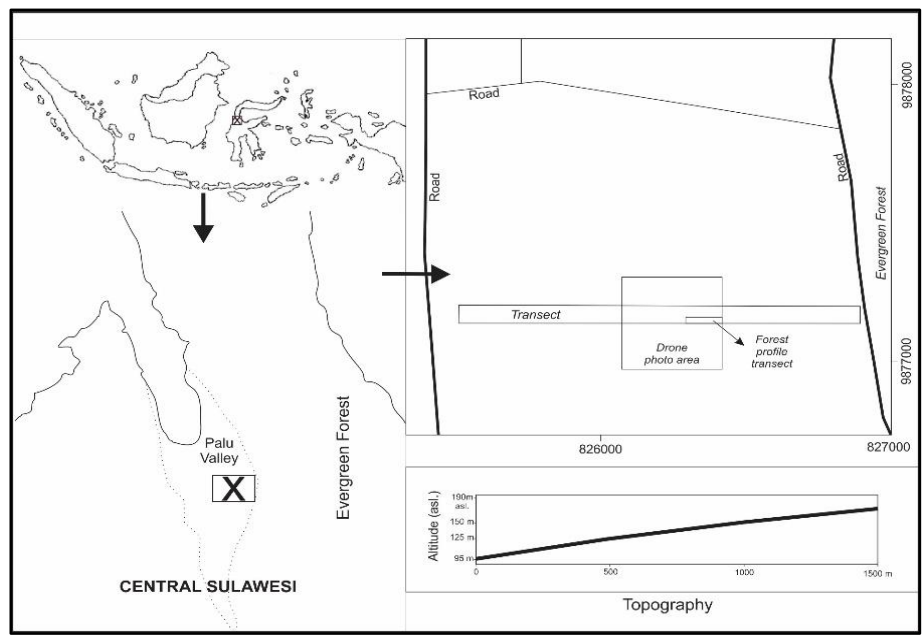

Fig. 1. Map of the research location in Biromuli District, Sigi Regency, Central Sulawesi Province 


\subsection{Data Analysis}

Data analysis was carried out by ranking each plant species from the most important to the least important using the species importance value index [18]. The species importance index is the sum of the relative values of frequency, density and basal area $[19,20]$. The importance of family value (FIV) was used, which is the sum of the relative values of the number of species, density and basal area, to obtain the value of the importance of species groups based on family [21].

The species diversity index was calculated using the Shannon formula, namely $\mathrm{H}^{\prime}=-\Sigma(\mathrm{n} / \mathrm{N})$ In $(\mathrm{ni} / \mathrm{N})$, where $\mathrm{ni}$ is the number of individuals of the ith species and $\mathrm{N}$ is the number of individuals of all species. The Shannon diversity index ranges from 1.5 to 3.5 and rarely reaches 4.5 [22]. Species diversity is categorized as low if $\mathrm{H}^{\prime}$ $<1$, moderate category if $1<\mathrm{H}^{\prime} \leq 3$ and high diversity if $\mathrm{H}^{\prime}>3$. To determine the stability of the community, it is calculated using the formula for the species evenness index $(E)$ using the formula $E=H^{\prime} / \log S$, where $H^{\prime}$ is the Shannon Index and $S=$ the number of species. Evenness index value $(E)$ ranged from $0-1$. The value of $E$, which is close to zero, indicates that the distribution of species is increasingly uneven in the community, on the contrary, the greater the value of $E$ or close to one, the distribution of species in the community is more even [23,24]. The community is categorized as depressed if the value of $E<$ 0.50 , unstable if $0.50<E<0.75$ and stable if $0.75<E<1.00$ [25]. All analyzes were performed using the Paleontological Statistics (PAST) software version 3:04 [26].

\section{RESULTS AND DISCUSSION}

\subsection{Results}

\subsubsection{Species diversity}

Based on the species area curve (Fig. 2), the cumulative number of species in each additional subplot showed the shape of the rungs of the curve, where no new additions were found in the last five subplots. A sign that the number of plots for dry deciduous forest type at the study site is considered sufficient [27]. A total of 24 species consisting of 22 genera and 14 families were identified from all plots. The Apocynaceae contained the highest number of species, individuals and area of the basal area which ultimately overall had the highest Family Importance Value (FIV) (Table 1). The most abundant member of the Apocynaceae family was Tabernaemontana pandacaqui with a density of 276 trees per ha or accounts for $97 \%$ of the total number of individuals of the Apocynaceae. The next important families based on their FIV were the Leguminosae and Rubiaceae. The most abundant members of the Leguminosae were Acacia nilotica (97 trees per ha), while Randia spinosa (73 trees per ha) was the abundant species in the Rubiaceae family.

In Table 2, a list of species (diameter $\geq 2 \mathrm{~cm}$ ) was presented, sorted by species importance value (SIV). The five species with the largest SIV were Tabernaemontana pandacaqui (67.18), A. nilotica (44.25), Jatropha gossypiifolia (32.60), Diospyros sp. (27.23) and Punica granatum (24.11). T. pandacaqui was highest in all elements measured, which indicated the dominance (highest ecological position) of this species in the community.

The community species diversity index $\left(\mathrm{H}^{\prime}\right)$ was recorded as 2.3880 which was classified as moderate category, while the species evenness index (E) was found as 0.75 which was indicated an unstable position and close to a stable level. If each of the 30 subplots is calculated the species diversity index, the magnitude ranges from 0.8676 to 2.2780. The lowest score was recorded in subplot 6 and the highest was in subplot 13. In general, the subplots had an index value of species diversity which was classified as moderate category, except for subplots 6 $(0.8676)$ and $21(0.9017)$ which were classified as low category $(\mathrm{H}<1)$. However, when viewed based on the evenness index, subplot 21 was the lowest $(E=0.4106)$ which indicated that the distribution of species in this subplot was uneven compared to other subplots. The abundance of Jatropha gossypiifolia which controls $77.3 \%$ of the tree population in subplot 21 may suppress other species. Similar data was also found in subplot 14 which had a low evenness value ( $E=$ $0.4734)$. In subplot $14 A$. nilotica emerged as the most dominant species and controlled $55.9 \%$ of the tree population in that subplot. With $E$ values $<0.50$, subplots 14 and 21 were also listed as the most depressed communities. Subplots 7,8 , $15,20,22,23$ and 25 were classified as unstable with $E$ values varying between 0.5731 and 0.7366, the remaining 21 subplots were classified as stable with $\mathrm{E}$ values $>0.75$ (Fig. 3 ). 


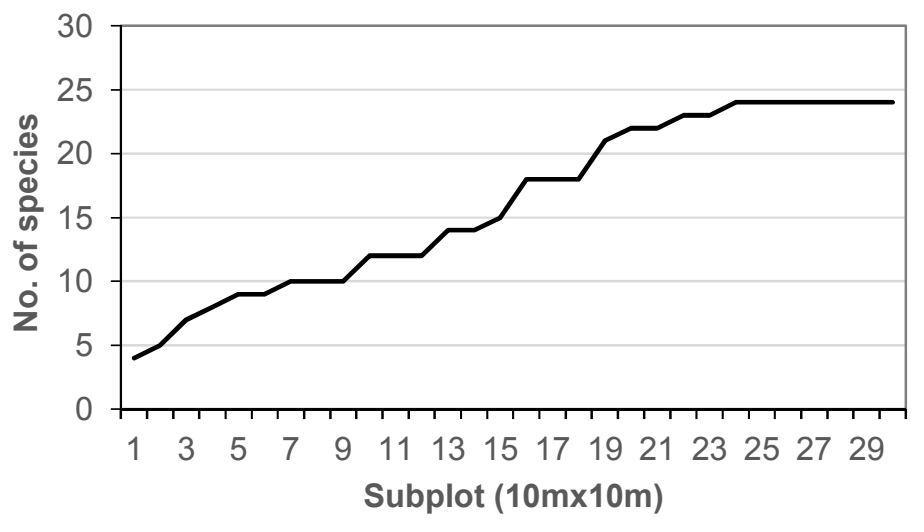

Fig. 2. Species-area curve at the study site

Table 1. Number of species, density, basal area (BA) and family importance value (FIV) of each family recorded from the study site

\begin{tabular}{llllll}
\hline SL. No. & Family & No. of species & Density (per ha) & BA ( $^{2}$ per ha) & FIV \\
\hline 1 & Apocynaceae & 4 & 286 & 0.7094 & 75.8445 \\
2 & Leguminosae & 2 & 172 & 0.5064 & 47.6462 \\
3 & Rubiaceae & 3 & 87 & 0.1608 & 27.9280 \\
4 & Euphorbiaceae & 1 & 160 & 0.1504 & 25.7487 \\
5 & Ebenaceae & 1 & 133 & 0.1405 & 22.8600 \\
6 & Annonaceae & 2 & 73 & 0.1101 & 20.1464 \\
7 & Lythraceae & 1 & 67 & 0.1972 & 19.4325 \\
8 & Lamiaceae & 2 & 43 & 0.0399 & 14.1160 \\
9 & Malvaceae & 2 & 9 & 0.0446 & 11.2610 \\
10 & Meliaceae & 2 & 16 & 0.0236 & 10.8916 \\
11 & Capparaceae & 1 & 27 & 0.0396 & 8.4413 \\
12 & Solanaceae & 1 & 17 & 0.0142 & 6.3472 \\
13 & Verbenaceae & 1 & 3 & 0.0053 & 4.7171 \\
14 & Sapindaceae & 1 & 3 & 0.0032 & 4.6196 \\
\hline
\end{tabular}
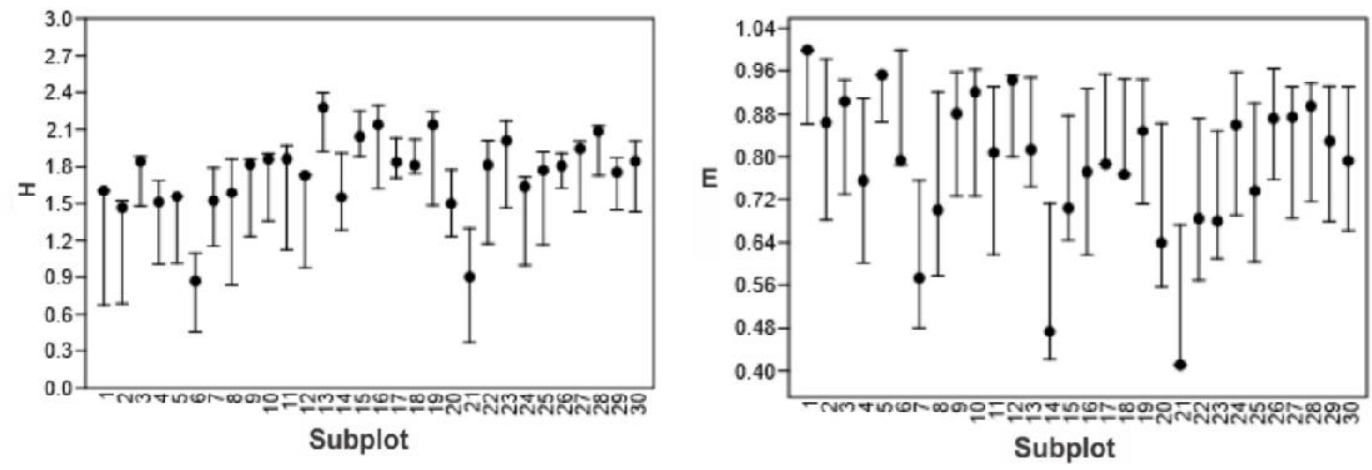

Fig 3. Shannon diversity index $(H)$ and evenness index $(E)$ in each subplot

\subsubsection{Vegetation structure}

All woody species (stem diameter $\geq 2 \mathrm{~cm}$ ) were recorded from the study area. This study revealed a total of 321 individuals with a density of 1,069 individuals per ha and a total basal area of $2.48 \mathrm{~m}^{2}$ per ha. The distribution of individuals based on stem diameter showed that the majority 
consisted of individuals with a diameter of 2.0-4.9 $\mathrm{cm}(62.9 \%)$, followed by individuals with a diameter of $5.0-9.9 \mathrm{~cm}(32.4 \%)$, while those with a diameter of $10 \mathrm{~cm}$ or more were only $4.7 \%$ (Fig. 4).

The tree level with stem diameter $\geq 10 \mathrm{~cm}$ has a density of 50 trees per ha with a total basal area of $0.60 \mathrm{~m}^{2}$ per ha. $A$. nilotica was the most abundant species with 30 trees per ha or $60 \%$ of the population of all tree species in diameter. This species also has the largest basal area of $0.39 \mathrm{~m}^{2}$ per ha or $64 \%$ of the total basal area of all trees with the widest distribution of individuals $(F=50 \%)$ (Table 2). At the belt level $(2 \leq$ diameter $<10 \mathrm{~cm})$, the individual density reached 1,019 individuals per ha with a total basal area of $1.87 \mathrm{~m}^{2}$ per ha. Judging from the distribution of individuals based on stem diameter, species that can reach stem diameter $\geq 10 \mathrm{~cm}$ such as Tabernaemontana pandacaqui, A. nilotica and Punica granatum have relatively the same pattern, which has the highest density in the diameter class $5.0-9.9 \mathrm{~cm}$, while Jatropha gossypiifolia and Diospyros sp. are abundant in the diameter class $<5 \mathrm{~cm}$ (Fig. 5). It is interesting to note the presence of $T$. pandacaqui and J. gossypiifolia. Both species were found growing in groups with high population densities. The largest population for J. gossypiifolia reached 1900 stems per ha and T. pandacaqui 1600 stems per ha which almost appeared as a homogeneous species in an area (Fig. 6).

Vertically, the stand structure shows a very simple canopy layer, consisting of only one main layer at a height of 4-7 m. The species that occupy the main canopy layer are generally inhabited by individuals with stem diameter $\geq$ $10 \mathrm{~cm}$, namely $A$. nilotica, $T$. pandacaqui, Leucaena leucocephala, Microcos sp. and $P$. granatum. J. gossypiifolia was found growing abundantly at a height of 2-3 $\mathrm{m}$ at the bottom of the main open canopy (gap).

Table 2. Density, basal area (BA), frequency (F) and species importance value (SIV) for tree species (diameter $\geq 2 \mathrm{~cm}$ ) recorded from the study site

\begin{tabular}{llllll}
\hline Scientific name of the species & Family & $\begin{array}{l}\text { Density } \\
\text { (per ha) }\end{array}$ & $\begin{array}{l}\text { BA } \\
\text { (m } \mathbf{m}^{2} \text { perha) }\end{array}$ & F (\%) & SIV \\
\hline Tabernaemontana pandacaqui Lam. & Apocynaceae & 276 & 0.6753 & 14.05 & 67.18 \\
Acacia nilotica (L.) Delile & Leguminosae & 97 & 0.5854 & 11.57 & 44.25 \\
Jatropha gossypiifolia L. & Euphorbiaceae & 160 & 0.1504 & 11.57 & 32.60 \\
Diospyros sp. & Ebenaceae & 133 & 0.1405 & 9.09 & 27.23 \\
Punica granatum L. & Lythraceae & 67 & 0.1972 & 9.92 & 24.11 \\
Leucaena leucocephala (Lam.) de Wit & Leguminosae & 47 & 0.2518 & 8.26 & 22.80 \\
Randia spinosa (Thunb.) Poir. & Rubiaceae & 73 & 0.1425 & 5.79 & 18.40 \\
Annona squamosa L. & Annonaceae & 63 & 0.0757 & 5.79 & 14.76 \\
Capparis sepiaria var. fischeri (Pax) & Capparaceae & 27 & 0.0396 & 4.13 & 8.22 \\
DeWolf & & & & & \\
Callicarpa sp. & Lamiaceae & 40 & 0.0367 & 2.48 & 7.70 \\
Annona muricata L. & Annonaceae & 10 & 0.0345 & 2.48 & 4.81 \\
Reinwardtiodendron humile (Hassk.) & Meliaceae & 13 & 0.0225 & 2.48 & 4.64 \\
Mabb. & & & & & \\
Solanum verbascifolium L. & Solanaceae & 17 & 0.0142 & 2.48 & 4.61 \\
Microcossp. & Malvaceae & 7 & 0.0338 & 1.65 & 3.64 \\
Ochrosia elliptica Labill. & Apocynaceae & 3 & 0.0236 & 0.83 & 2.09 \\
Diplospora sp. & Rubiaceae & 7 & 0.0094 & 0.83 & 1.83 \\
Randia longiloba Hemsl. & Rubiaceae & 7 & 0.0088 & 0.83 & 1.81 \\
Pterospermum diversifolium Blume & Malvaceae & 3 & 0.0107 & 0.83 & 1.57 \\
Wrightia pubescens R.Br. & Apocynaceae & 3 & 0.0094 & 0.83 & 1.52 \\
Lantana camara L. & Verbenaceae & 3 & 0.0053 & 0.83 & 1.35 \\
Gmelina sp. & Lamiaceae & 3 & 0.0032 & 0.83 & 1.27 \\
Sapindussp. & Sapindaceae & 3 & 0.0032 & 0.83 & 1.27 \\
Aglaia sp. & Meliaceae & 3 & 0.0010 & 0.83 & 1.18 \\
Calotropis gigantea (L.) Dryand. & Apocynaceae & 3 & 0.0010 & 0.83 & 1.18 \\
\hline
\end{tabular}



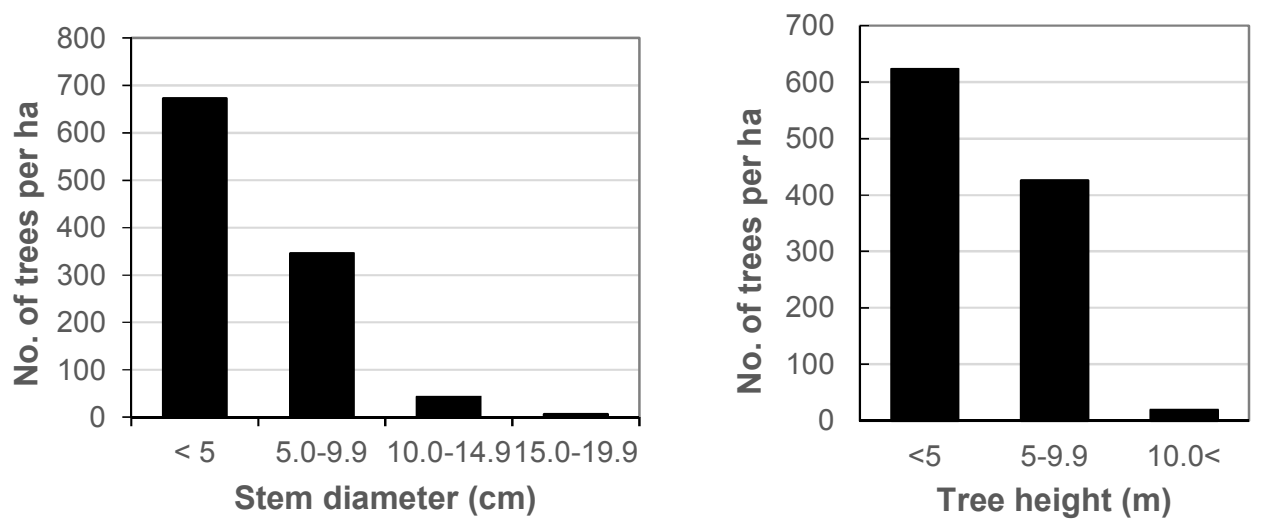

Fig. 4. Tree distribution based on stem diameter (left) and tree height (right)

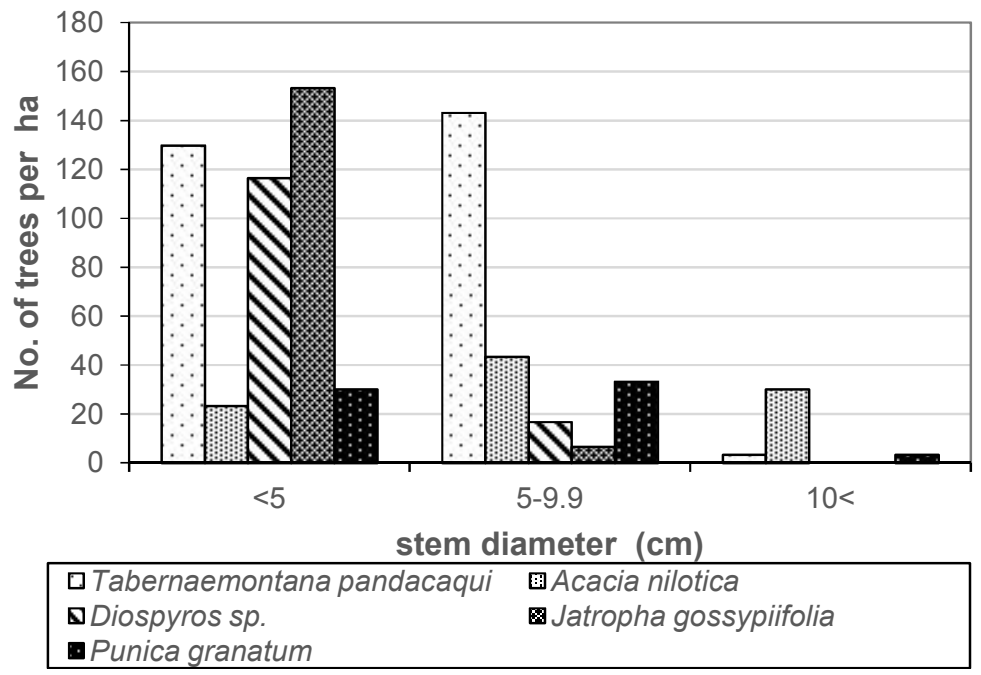

Fig. 5. Individual distribution of five main species based on stem diameter class

The condition of the forest profile assessed through transect $(7 \mathrm{~m} \times 100 \mathrm{~m})$ is presented in Fig. 6 . The species depicted on the transect include tree species that are not chopped in the plot such as Dracaena draco. Other species that were not enumerated in plots and transects but found in the area were Tamarindus indica, Lannea coromandelica and Ceiba pentandra. T. indica and $C$. pentandra were the most prominent species with a height of $10-15 \mathrm{~m}$.

\subsubsection{Regeneration}

This study revealed a total of 21 regenerating species belonging to 21 genera and 17 families. Herbaceous grasses and small shrubs emerged as the dominant species over trees. The five main species at the seedling and understory levels based on species importance value (SIV) were Digitaria ciliaris, A. nilotica, Chromolaena odorata, Sida acuta and Randia spinosa (Table 3 ). From the composition of the seedling species, it appears that as many as 12 species (50\%) [enlisted in Table 2 (stem diameter $\geq 2 \mathrm{~cm}$ )] did not have regeneration at the seedling level. Species that reached a stem diameter of $\geq 10 \mathrm{~cm}$ showing dominance at the seedling level was $A$. nilotica. Annona muricata, Punica granatum and Microcos sp. were not found to show the regeneration potential at the seedling level.

\subsubsection{Population and distribution of Acacia nilotica}

One interesting note is the emergence of $A$. nilotica which was dominant at all growth stages 
(Tables 2 and 3 ). The findings of the study showed that $A$. nilotica is spread in the plot with a frequency of $11.6 \%$. The number of $A$. nilotica individuals ranged from 1-6 trees in a $100 \mathrm{~m}^{2}$ plot, but at one location outside the plot it was found to grow homogeneously with a density of 8 trees per $100 \mathrm{~m}^{2}$ or 800 trees per ha. Using drone image analysis with processing statistical training area the digital number of each sensor, canopy cover as $A$. nilotica could be interpretete quickly and with precision.
Sample data from GPS coverage of $A$. nilotica from the field is used as a training area for $\mathrm{UAV} /$ drone images. It is therefore expected that the delimited area is properly identified under $A$. nilotica cover and other types of cover (other vegetation and open land). The training area aims to obtain spectral class value data on each channel R(red), G (Green) and B (Blue). The data set for the spectral values will then be calculated for the distribution of statistical data.

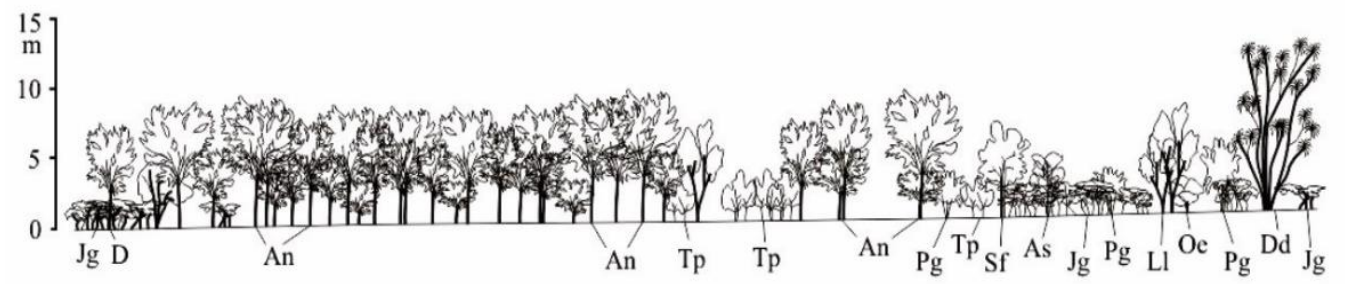

An-Acacia nilotica; As-Annona squamosa; D-Diospyros sp.; Dd-Dracaena draco; Jg-Jatropha gossypiifolia; LI-Leucaena leucocephala; Oe-Ochrosia elliptica; Pg-Punica granatum; Sf-Sterculia foetida; Tp-Tabernaemontana pandacaqui.

Fig. 6. Forest profile on transect $(7 \mathrm{~m} \times 100 \mathrm{~m})$

Table 3. Relative dominance (Rd), relative frequency (Rf) and species importance value (SIV) of seedlings and undergrowth (diameter $<2 \mathrm{~cm}$ ) at the study site

\begin{tabular}{llllll}
\hline SL. No. & Scientific name of the species & Family & Rd & Rf & SIV \\
\hline 1 & Digitaria ciliaris (Retz.) Koeler & Poaceae & 40.41 & 14.10 & 54.51 \\
2 & Acacia nilotica (L.) Delile & Leguminosae & 10.50 & 17.95 & 28.45 \\
3 & Chromolaena odorata (L.) & Compositae & 17.64 & 8.97 & 26.61 \\
& R.M.King\&H.Rob. & & & & \\
4 & Sida acuta Burm.f. & Malvaceae & 4.31 & 10.26 & 14.56 \\
5 & Randia spinosa (Thunb.) Poir. & Rubiaceae & 5.53 & 7.69 & 13.22 \\
6 & Jatropha gossypiifolia L. & Euphorbiaceae & 5.06 & 7.05 & 12.11 \\
7 & Tabernaemontana pandacaqui Lam. & Apocynaceae & 2.65 & 5.13 & 7.78 \\
8 & Leucaena leucocephala (Lam.) de Wit & Leguminosae & 1.81 & 5.13 & 6.94 \\
9 & Cyathula prostrata (L.) Blume & Amaranthacea & 1.03 & 5.77 & 6.80 \\
& & e & & & \\
10 & Phyllanthus reticulatus Poir. & Phyllanthaceae & 1.99 & 3.85 & 5.83 \\
11 & Diospyros sp. & Ebenaceae & 3.76 & 1.28 & 5.04 \\
12 & Calanchoesp. & Crassulaceae & 2.53 & 1.28 & 3.81 \\
13 & Gmelina sp. & Lamiaceae & 0.51 & 3.21 & 3.71 \\
14 & Callicarpa sp. & Lamiaceae & 0.40 & 3.21 & 3.60 \\
15 & Sapindus sp. & Sapindaceae & 0.33 & 1.28 & 1.61 \\
16 & Ziziphus oenopolia (L.) Mill. & Rhamnaceae & 0.58 & 0.64 & 1.22 \\
17 & Annona squamosa L. & Annonaceae & 0.36 & 0.64 & 1.00 \\
18 & Arytera sp. & Sapindaceae & 0.29 & 0.64 & 0.93 \\
19 & Croton hirtus L'Hér. & Euphorbiaceae & 0.22 & 0.64 & 0.86 \\
20 & Lantana camara L. & Verbenaceae & 0.07 & 0.64 & 0.71 \\
21 & Solanum verbascifolium L. & Solanaceae & 0.04 & 0.64 & 0.68 \\
\hline
\end{tabular}


The results of the statistical data processing on the image along with the index value with the standard deviation and the average value get the range of vegetation type class profiles (Fig. 7). The middle and upper ranges of $A$. nilotica have different ranges from other vegetation but based on the minimum standard deviation of the range, this class has been mixed with other vegetation classes that have maximum standard deviations. This condition facilitates the classification process in raster analysis.

From the mapping analysis results it was observed that the distribution of $A$. nilotica was dominant in clusters located at the upper left of plot area (Fig. 8). Mapping analyses identified $A$. nilotica canopy class and the other vegetation at 10.24 ha area by the classification of based pixel statistical. This study disclosed the proportion of A. nilotica canopy cover which was 1.99 ha or approximately $19 \%$ in the study area (Fig. 9). This condition indicated the potential for invasion of this species in the area, which can later add to the condition of open land that is detected and leaves $12 \%$ of the area.

\subsection{Discussion}

\subsubsection{Forest stand}

Dry deciduous forests are also well known as Seasonally Dry Tropical Forest (SDTF) [28], in Asian countries. This type of forest usually experiences multiple fires incidents and mostly is undergoing secondary succession [29]. Forests at the study site can generally be classified as remaining forest or young secondary forest undergoing a succession process. Fires and logging are two main causes that severely deteriorated the forest vegetation in this area. Sandy land conditions with low soil water and organic matter content of this area also have positive influence on the growth of forest species; hence many species are able to grow on it.

In Sigi dry forest, Tabernaemontana pandacaqui represented the highest Species Importance Value (SIV), which indicated the high ecological position of this species in the plant community. $T$. pandacaqui is highly adaptive to a wide range of habitat conditions, from relatively open shrubs, dry limestone outcrops, to periodically inundated river and swamp forest [30]. Euphorbiaceae, which often appears as the most dominant family in the tropics of Malesia [3,31-33], in this study appeared in the fourth rank with only Jatropha gossypiifolia represented and had the third rank in individual abundance (160 stems per ha). The seed dispersal system of species belonging to the Euphorbiaceae family is known to be very effective, especially through birds and mammals [34]. In terms of the vegetation structure, Sigi dry forest has shown to have an ' $L$ ' shaped. An 'L'shaped graph model in which populations decline in the large diameter class is common in tropical forests [35-42]. The steepness of the graph in this case is caused by the dominance of small but mature species. Species that have stem diameter $\geq 10 \mathrm{~cm}$ are generally also dominated by small trees that already have a mature growth stage. Dry deciduous forests are relatively rare with tree species sticking out above $25 \mathrm{~m}$. Generally rarely straight trunked, low branched, the number of species are few and tend to be local dominant [2]. In Southern India, dry deciduous forest species have, on average, lower both of diameter ratios and specific leaf areas, than evergreen forest species. However, they have higher of wood densities and relative bark thickness [43]. In terms of its vertical structure, it is known that species such as Tamarindus indica and Ceiba pentandra are the most prominent species with a height of $10-15 \mathrm{~m}$. These species are known to be native to several savanna and dry deciduous forests in Indonesia $[4,5]$. Malvaceae (Ceiba) is known to have also to have occur in other SDTF such as in interAndean valleys and central Andes Coast [44]. A number of $T$. indica also distributes at Baluran National Park dry forest in East Java Province [7], as well as at Komodo Island of the Komodo National Park, East Nusa Tenggara Province [45].

\subsubsection{Invasion of Acacia nilotica}

Acacia nilotica is easily growing in dry conditions with an annual rainfall of $250-1500 \mathrm{~mm}$ [46], although it depends on the variety of climatic factors [47]. Several reports have stated that $A$. nilotica is the dominant species in savanna and dry deciduous forests in Africa [48,49], Australia, especially in Queensland [50-55], India $[43,56,57]$ and Baluran savanna, East Java, Indonesia $[7,58]$. Initial information on the entry of $A$. nilotica in the Palu Valley was obtained from Setiabudi et al. [59] who reported that $A$. nilotica was sent to Palu from the Bogor Botanic Gardens, after research of extracting Arabic gum from the plant was abandoned around 1890. In other areas, it was initially promoted as a tree that can provide protein supplements and various other purposes in agriculture. In Baluran National Park, A. nilotica was initially planted in the 1970 s 
as firebreaks so that fires do not spread to teak forests. However, recently it has become an invasive species and threatens grasslands as animal feed providers in various savanna areas $[7,52]$. Carter [52] reported that $A$. nilotica invasion resulted in a $50 \%$ reduction in grasslands in $25-30 \%$ tree canopy cover in Queensland, Australia. Mackey [53] also reported that within 10 years of its introduction, A. nilotica had expanded to 7 million ha in Queensland, Australia. Research conducted by Sutomo et al. [7] also reported that the invasion of $A$. nilotica had encroached on the savanna area in Baluran National Park and caused a reduction in savanna land. From the research results of Sutomo et al [60] using remote sensing it was also disclosed that during 2000 to 2014 there has been a reduction in savanna area of 1.361 ha. Since the introduction of $A$. nilotica in Queensland in the 1890s, 67 years later this species has been declared as dangerous to the environment [53]. Indeed, remote sensing has long been known as useful tools in detecting patterns over large scale landscape. It has also been used in detecting species such as $A$. nilotica $[61,62]$.

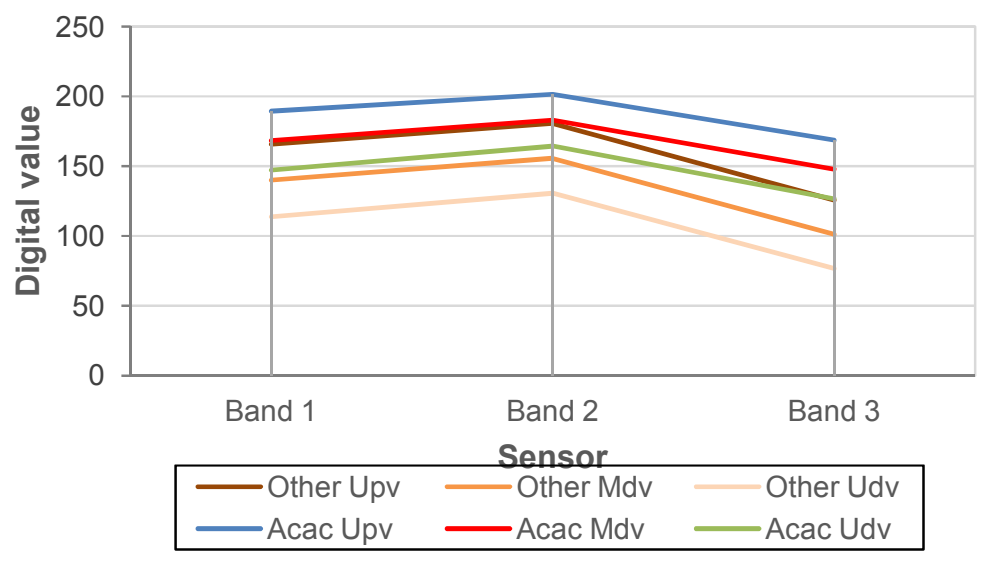

Fig. 7. Profile spectral Acacia nilotica (Gradient Red) compare with other vegetation (Gradient Green) on RGB system

*note: Other (other vegetation), Acac (Acacia nilotica), Upv (Upper value pixel),Mdv (Midle value pixel), Udv (Under Value Pixel).

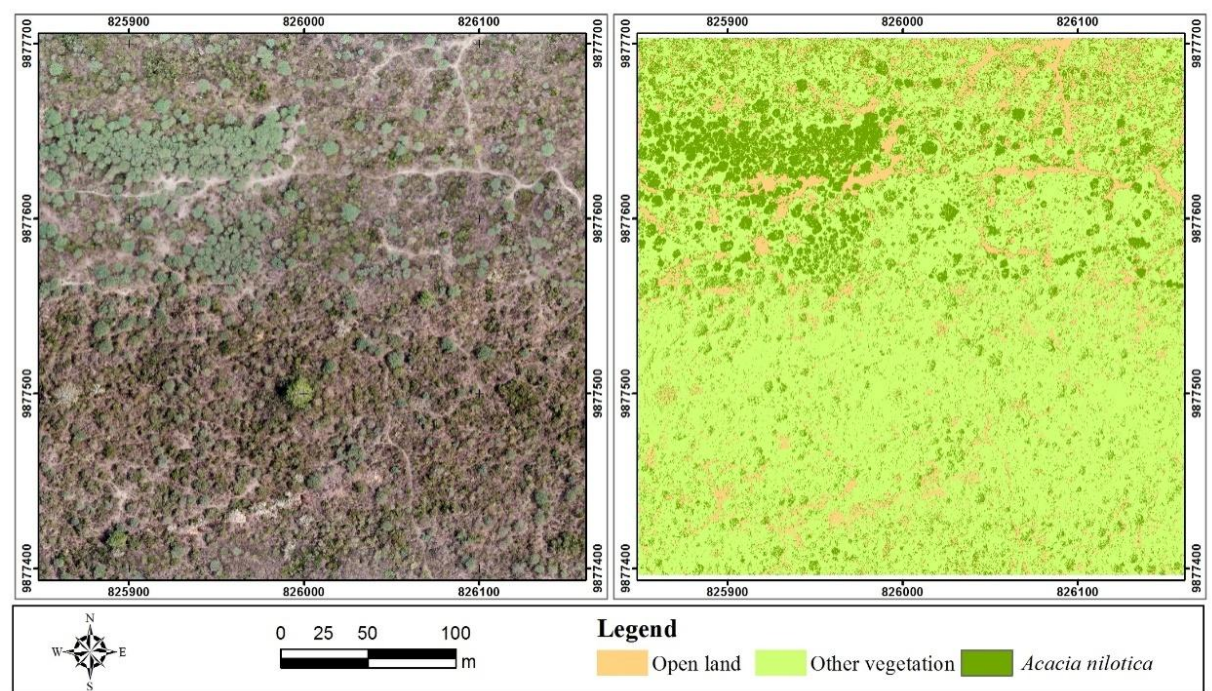

Fig. 8. Landscape area captured through drone Image (left) and distribution of Acacia nilotica (right) in 10.24 ha plot 


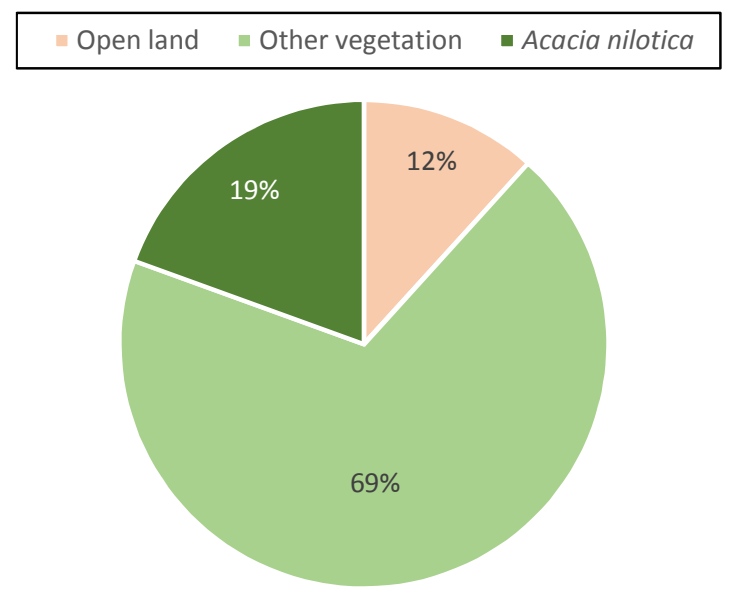

Fig. 9. Proportion of classification coverage of Acacia nilotica in 10.24 ha plot

A. nilotica could grow even in a poor nutrient soil such as poor soil of Central Sulawesi, Indonesia. In fact like other legume species it has the capability to improve soil nutrients. Several research findings reported that the $A$. nilotica tree improves soil fertility under its canopy by reducing the proportion of sand while increasing the proportion of clay particles, owing to the protection of the soil from the impact of raindrops [63]. In addition, $A$. nilotica is well nodulated with Rhizobium species [64]. This nodulation behavior aids in biological nitrogen fixation, which aids in meeting nitrogen requirements in nutrientdepleted soils.

Wind, water and livestock are considered as the main agents for the dispersal of $A$. nilotica seeds $[52,55]$. Seeds of $A$. nilotica can survive for 6 days in the intestines of mammals such as sheep and cattle which are included when cattle are moved to other places [53]. In the case of Baluran National Park, the dominance of $A$. nilotica in the Savanna area is due to the abundant of buffalo population. A research conducted by Sutomo and van Etten [65] found that in summer when grass is not widely available, buffalo consume $A$. nilotica pods and its seeds come out along with their stools. It was estimated that in 500 grams of feces can be found hundreds of seeds $A$. nilotica. As soon as the first rain the seeds then germinate quickly and healthily. Because the range of this buffalo is also wide in the Baluran National Park area, $A$. nilotica can be spread throughout the savanna and dry forests in the Baluran National Park.

Plant interaction such as competition for space has been observed in A. nilotica stand where it was observed that the area under the stand is cleared from groundcover species. Plant interaction in a form of biochemical signal such as allelopathy is assumed to have caused this condition [66]. A.nilotica grows naturally in agricultural fields throughout the Indian subcontinent, forming an important agroforestry system [67]. It has been reported that $A$. nilotica reduces crop yield under its canopy in general, and that this reduction varies with distance from the tree trunk [67,68]. Duhan and Lakshinarayana [69] discovered that the presence of allelochemicals such as tannins, flavonoids, and phenolic acids affects the growth of Cyamopsis tetragonoloba and Pennisetum glaucumgrowing at $1-2$ and $7.5 \mathrm{~m}$ distances from an $A$. nilotica tree on seed germination and seedling growth. These proteins are in charge of cellular processes such as plant growth enhancement, physiological and molecular functions $[63,70]$.

Come across at other research, there are similar cases where $A$ nilotica is an important component of SDTF [71,72]. A. nilotica is known to have efficiency in nodulation [71]. In India SDTF's it is evidence that seedlings from smaller seeds, particulary of fast growing species, is able to withstand drought by morphogenetic and physiological plastic response better than large seeds species [72].

Therefore, by looking at events in other areas, the dominance of $A$. nilotica in the study area is likely to continue considering that its regeneration is relatively available. Controlling the presence of species can be one or several specific species, but it can also be due to the 
physical nature of the habitat. There is no clear boundary whether the influence of species or habitat factors, both can operate together and influence each other [73]. There are other factors that are more influential, for example the seed dispersal system of $A$. nilotica. It is suggested that controlling the dispersal agent can also be one of the options to suppress the domination of the species.

\section{CONCLUSION}

The dry forest of Sigi is the remaining deciduous forest in the Palu valley, Central Sulawesi Indonesia. This ecologically important forest area needs to be preserved for proper biological functioning. The forest is categorized as growing deciduous forest, but the invasion of Acacia nilotica, which now accounts for $19 \%$ of the total plot area, needs to be anticipated. Without proper control, it is feared that the remaining deciduous forest in the Palu Valley will turn into a stretch of $A$. nilotica. A more in-depth investigation of the seed dispersal agent of $A$. nilotica is required, including wind characteristics, surface runoff patterns, and livestock behavior in the area. If these agents are shown to be the cause of $A$. nilotica invasion, needs many preventive measures, such as windbreaks, pathway construction, ditch arrangements, and animal fencing, must be implemented. We recommended mechanical uprooting of $A$. nilotica and re-plant it with native species to successfully avoid $A$. nilotica invasion.

\section{ACKNOWLEDGEMENTS}

Thanks are conveyed to the head and staff of the Sigi Regency Environmental Service for their financial support and assistance during data collection in the field. Thanks also to the Head of the Research Center for Plant Conservation and Botanic Gardens, Indonesian Institute of Sciences (LIPI) for their support so that this research is carried out.

\section{COMPETING INTERESTS}

Authors have declared that no competing interests exist.

\section{REFERENCES}

1. Biology Dictionary. Deciduous forest. Accessed 2 February 2021.
Available:https://biologydictionary.net/decid uous-forest/

2. Kartawinata K. Diversitas ekosistem alami Indonesia. Ungkapan singkat dengan sajian foto dan gambar. Jakarta: LIPI Press - Yayasan Pustaka Obor Indonesia. Indonesia; 2013.

3. Whitmore TC. Tropical rain forests of the far east. 2nd ed. Oxford University Press; 1986.

4. Whitten T, Soeriaatmadja RE, Afiff SA. Ecology of Java and Bali. The Ecology of Indonesia Series. Volume II. Oxford University Press. Periplus Editions (HK) Ltd; 1997.

5. Monk KA, de Fretes Y, Lilley GR. Ecology of Nusa Tenggara and Maluku. The Ecology of Indonesia series. Volume $\mathrm{V}$. Dalhousie University. Periplus Editions (HK) Ltd; 1997.

6. Meijer-Drees E. Distribution, ecology and silvicultural possibilities of the trees and shrubs from the savanna forest region in Eastern Sumbawa and Timor (Lesser Sunda Islands). Communication of the Forest Research Institute. 1951;33:1-146.

7. Sutomo S, van Etten E, Wahab L. Proof of Acacia nilotica stand expansion in Bekol Savanna, Baluran National Park, East Java, Indonesia through remote sensing and field observations. Biodiversitas. 2016;17(1):96-101

8. Siregar M, Yuswandi AY. Alternatif lokasi pengembangan kebun raya dan eksplorasi tumbuhan hutan monsun meranggas berbasis peta distribusi tipe hutan di Nusa Tenggara. Buletin Kebun Raya. 2018;21(2):67-82. Indonesia.

9. Robichaux $\mathrm{RH}$, Yetman D, editors. The tropical deciduous forest of Alamos: Biodiversity of a threatened ecosystem in Mexico. University of Arizona Press; 2000.

10. Anonymous. Top 5 largest island in Indonesia. Factsofindonesia; 2021.

Accessed 21 July 2021.

Available:https://factsofindonesia.com/larg est-islands-in-indonesia.

11. Whitten $\mathrm{T}$, Henderson GS, Mustafa M. Ecology of Sulawesi. The Ecology of Indonesia series. Volume IV. Gadjah Mada University Press. Periplus Editions (HK) Ltd; 1987.

12. Siregar M, Helmanto H, Rakhmawati SU. Vegetation analysis of tree communities at some forest patches in North Sulawesi, Indonesia. Biodiversitas. 2019;20(3):643655. 
13. Purnomo DW, Siregar $M$, Lubis RF, Hidayat A, Suhendar, Widoretno A, et al. Laporan akhir master plan Kebun Raya Sigi. Bogor: Pusat Penelitian Konservasi Tumbuhan dan Kebun Raya LIPI, Dinas Lingkungan Hidup Kabupaten Sigi; 2019. Indonesia.

14. Supartoyo, Cipta A, Solikhin A, Hidayati S, Effendi R. Tingkat guncangan dan skala Intensitas Gempa bumi. In: Andiani, Oktariadi $\mathrm{O}$, Kurnia $\mathrm{A}$, editors. Di balik pesona Palu, bencana melanda, geologi menata. Bandung: Badan Geologi, Kementerian Energi dan Sumber Daya Mineral; 2018. Indonesia.

15. Tuhid NH, Abdullah NE, Khairi NM, Saaid MF, Shahrizam MSB, Hashim H. A statistical approach for orchid disease identification using RGB color. 2012 IEEE Control and System Graduate Research Colloquium. 16-17 Juli 2012:382-385. DOI: 10.1109/ICSGRC.2012.6287196.

16. Zhang $X$, Zhang F, Qi Y, Deng L, Wang X, Yang $S$. New research methods for vegetation information extraction based on visible light remote sensing images from an unmanned aerial vehicle (UAV). International Journal of Applied Earth Observation and Geoinformation. 2019;78:215-226.

17. Aslan A, Rahman AF, Warren MW, Robeson SM. Mapping spatial distribution and biomass of coastal wetland vegetation in Indonesian Papua by combining active and passive remotely sensed data. Remote Sensing of Environment. 2016;183:65-81.

18. Lamont BB, Downes S, Fox JED. Importance-value curves and diversity indices applied to a species-rich heathland in Western Australia. Nature. 1977;265:438-441.

19. Curtis JT, Mclntosh RP. The interrelations of certain analytic and synthetic of phytosociological characters. Ecology. 1950;31:434-455.

20. Mueller-Dombois D, Ellenberg H. Aims and methods of vegetation ecology. New York: John Wiley \& Sons; 1974.

21. Mori SA, Boom BM, de Carvalho AM, dos Santos TS. Ecological importance of Myrtaceae in an Eastern Brazilian West Forest. Biotropica. 1983;15(1):68-70.

22. Gaines WL, Harrod JR, Lehmkuhl JF. Monitoring biodiversity: quantification and interpretation. General technical report PNW-GTR-443, USDA Forest Service,
Pacific North-West Research Station; 1999.

23. Magurran AE. Ecological diversity and its measurement. New Jersey (US): Princeton University Press; 1988.

24. Krebs CJ. Ecology. The experimental analysis of distribution and abundance. New York: Addison-Wesley Educational Publishers; 1994.

25. Pielou EC. The Measurement of diversity in different types of biological collections. Journal of Theoretical Biology. 1966;13: 131-144.

26. Hammer O. PAST-Paleontological statistics. version 3.04. Norway: Natural History Museum, University of Oslo; 2014.

27. Scheiner, SM. Six types of species-area curves. Global Ecology \& Biogeography. 2003;12:441-447.

28. Vieira DL, Scariot A. Principles of natural regeneration of tropical dry forests for restoration. Restoration Ecology. 2006; 14:11-20.

29. Dale VH. The role of disturbance in seasonally dry tropical forest landscapes. In: McShea WJ, Davies SJ, N. Bhumpakphan $\mathrm{N}$, editors. The ecology and conservation of seasonally dry forests in Asia. Washington DC: Smithsonian Institution Scholarly Press. 2011;75-96.

30. Chua LSL, Horsten SFAJ. Tabernaemontana L. In: van Valkenburg $\mathrm{JLCH}$, Bunyapraphatsara N, editors. Plant resources of south-east Asia No. 12(2): Medicinal and poisonous plants 2. Bogor: PROSEA Foundation; 2001.

31. Davies SJ, Becker P. Floristic composition and stand structure of mixed dipterocarp and heath forests in Brunei Darussalam. Journal of Tropical Forest Science. 1996;8(4):542-569.

32. Sist $P$, Saridan A. Stand structure and floristic composition of a primary lowland dipterocarp forest in East Kalimantan. Journal of Tropical Forest Science. 1999;11(4):704-722.

33. Djarwaningsih T. Keanekaragaman jenis Euphorbiaceae (jarak-jarakan) endemik di Sumatra. Jurnal Biodjati. 2017;2(2):89-94. Indonesia.

34. van der Pijl L. Principles of dispersal in higher plants. Berlin: Spingerverlag; 1982.

35. Hartshorn GS. Neotropical forest dynamics. Tropical succession. Biotropica, Suppl. 1980;12(2):20-30. 
36. Lorimer CG. Age structure and disturbance history of a southern appalachian virgin forest. Ecology. 1980;61:1169-1184.

37. Proctor J, Anderson JM, Chai P, Vallack HW. Ecological studies in four contrasting lowland rain forests in Gunung Mulu National Park, Serawak. I. Forest environment, structure and floristics. Journal of Ecology. 1983;71:237-260.

38. Mori SA, Rabelo BV, Tsou CH, Daly D. Composition and structure of an Eastern Amazonian forest at Camaipi, Amapa, Brazil. Boletim do Museu Paraense Emilio Goeldi. Serie Botanica. 1989;5:3-18.

39. Leak WA. Long-term structural change in uneven-aged northern hardwoods. Forestry Science. 1996;42:160-165.

40. Kartawinata K, Samsoedin I, Heriyanto M, Afriastini JJ. A tree species inventory in a one-hectare plot at the Batang Gadis National Park, North Sumatra, Indonesia. Reinwardtia. 2004;12(2):145-157.

41. Simbolon $H$. Dynamics of mixed Dipterocarps forests in Wanariset Semboja, East Kalimantan after three times of forest fires within the periods of 1980-2003. Biodiversitas. 2005;6(2):133137.

42. Aigbe HI, Omokhua GE. Modeling diameter distribution of the tropical rainforest in Oban Forest Reserve. Journal of Environment and Ecology. 2014;5(2): 130-143.

43. Ratnam J, Chengappa SK, Machado SJ, Nataraj N, Osuri AM, Sankaran M. Functional traits of trees from dry deciduous "forests" of southern India suggest seasonal drought and fire are important drivers. Frontiers in Ecology and Evolution. 2019;7(8):1-6.

44. Banda K, Delgado-Salinas A, Dexter KG, Linares-Palomino $R$, Oliveira-Filho $A$, Prado $D$, et al. Plant diversity patterns in neotropical dry forests and their conservation implications. Science. 2016;353(6306):1383-1387.

45. Sutomo S, Darma IDP, Iryadi R. The dissimilarity in plant species composition of savanna ecosystem along the elevation gradient on Flores Island, East Nusa Tenggara, Indonesia. Biodiversitas Journal of Biological Diversity. 2020;21(2):492496.

46. Anonymous. Acacia nilotica (gum arabic tree). Invasive species compendium. CABI; 2019.
Accessed 4 June 2021.

Available:https://www.cabi.org/isc/datashe et/2342.

47. Fagg CW. Acacia nilotica - pioneer for dry lands. NFT Highlights No. 92-04; 1992.

48. Brenan JPM. Manual on taxonomy of Acacia species: Present taxonomy of four species of Acacia (A. albida, A.senegal, A. nilotica, $A$. tortilis). Rome: United Nations FAO; 1983.

49. Skowno ALM, Bond WJ, Balfour D. Secondary succession in Acacia nilotica (L.) savanna in the Hluhluwe Game Reserve, South Africa. Plant Ecology. 1999;145:1-9.

50. Reynolds JA, Carter JO. Woody weeds in central western Queensland. Perth: Proceedings 6th Biennial Conference, Australian Rangelands Society, Carnarvon; 1990.

51. Burrows WH, Carter JO, Scanlan JC, Anderson ER. Management of savannas for livestock production in North-East Australia: Contrast across the tree-grass continuum. In: Werner PA, editor. Savanna Ecology and Management. London: Blackwell; 1991.

52. Carter JO. Acacia nilotica: a tree legume out of control. Forage tree legumes in tropical agriculture. 1994:338-351.

53. Mackey AP. Prickly Acacia (Acacia nilotica) in Queensland. Pest status review series - land protection branch. Queensland: Department of Natural Resources and Mines; 1996.

54. Radford IJ, Nicholas MD, Brown JR. Impact of prescribed burning on Acacia nilotica seed banks and seedlings in the Astrebla grasslands of Northern Australia. Journal of Arid Environments. 2001;49:795-807.

55. Weber E. Invasive plant species of the world: A reference guide to environmental weeds. Wallingford, UK: CAB International; 2003.

56. Singh SP. Growth studies of Acacia nilotica. Indian Forester. 1982;108(4):283288.

57. Troup RS, Joshi HB. The silviculture of Indian trees. Vol IV. Leguminosae. Delhi, India: Controller of Publications; 1983.

58. Djufri. Acacia nilotica (L.) Willd. ex Del. and problematical in Baluran National Park, East Java. Biodiversitas. 2004;5:96-104.

59. Setiabudi, Tjitrosoedirdjo S, Tjitrosoedirdjo SS, Mawardi I, Bachri S. Invansion of Acacia nilotica into savannas inside 
Baluran National Parks, East Java, Indonesia. Technical Papers Invasive Weeds, Ecology and Management. Bandung: Proc. 24 ${ }^{\text {th }}$ Asian-Pasific Weed Science Society Conference. 2013;23-25.

60. Sutomo S, van Etten E, Iryadi R. Use of landsat imagery to map spread of the invasive alien species Acacia nilotica in Baluran National Park, Indonesia. BIOTROPIA-The Southeast Asian Journal of Tropical Biology. 2020;27(1):88-96.

61. Sharma KD, Singh S, Singh N, Bohra DN. Satellite remote sensing for detecting the temporal changes in the grazing lands. Journal of The Indian Society of Remote Sensing. 1989;17(4):55-59.

62. Lawes RA, Wallace JF. Monitoring an invasive perennial at the landscape scale with remote sensing. Ecological Management and Restoration. 2008;9(1): 53-59.

63. Bargali K, Bargali SS. Acacia nilotica: a multipurpose leguminous plant. Nature and Science. 2009; 7(4):11-19.

64. Dreyfus BL, Dommergues YR. Nodulation of Acacia species by fast- and slowgrowing tropical strains of Rhizobium. Applied and Environmental Microbiology. 1981;41:97-99.

65. Sutomo S, van Etten E. Effect of fire and digestion by herbivores on seeds of the exotic invasive species Acacia nilotica from savanna at Baluran National Parks, Indonesia. Australasian Plant Conservation. 2016;25:20-21.

66. El-Khawas SA, Shehata MM. The allelopathic potentialities of Acacia nilotica and Eucalyptus rostrata on monocot (Zea mays L.) and dicot (Phaseolus vulgaris L.) plants. Biotechnology. 2005;4(1):23-34.

67. Pandey CB, Pandya KS, Pandey D, Sharma RB. Growth and productivity of rice (Oryza sativa) as affected by Acacia nilotica in a traditional agroforestry system. Tropical Ecology. 1999;40(1):109-117.

68. Bargali SS, Singh SP, Pandya KS. Effect of Acacia nilotica on gram crop in a traditional agroforestry system of Chhattisgarh plains. International Journal Ecology and Environmental Sciences. 2004;30(4):363-368.

69. Duhan JS, Lakshinarayana K. Allelopathic effect of Acacia nilotica on cereal and legume crops grown in fields. Allelopathy Journal. 1995;2(1):93-98.

70. Wang WX, Vinocur B, Shoseyov O, Altman A. Role of plant heat shock proteins and molecular chaperones in the abiotic stress response. Trends Plant Science. 2004; 9(5): z244-252.

71. Khurana E, Singh JS. Ecology of seed and seedling growth for conservation and restoration of tropical dry forest: a review. Environmental conservation. 2001; 28(1):39-52.

72. Khurana E, Singh JS. Germination and seedling growth of five tree species from tropical dry forest in relation to water stress: impact of seed size. Journal of Tropical Ecology. 2004;20(4):385-396.

73. Barbour GM, Busk JK, Pitts WD. Terrestrial plant ecology. New York: The Benyamin/Cummings Company, Inc; 1987.

( 2021 Siregar et al.; This is an Open Access article distributed under the terms of the Creative Commons Attribution License (http://creativecommons.org/licenses/by/4.0), which permits unrestricted use, distribution, and reproduction in any medium, provided the original work is properly cited. https://www.sdiarticle4.com/review-history/71424 